\title{
WestVirginiaUniversity
}

THE RESEARCH REPOSITORY @ WVU

2009

\section{National and State Economic Impact of NETL}

\author{
Randall Jackson \\ West Virginia University \\ Amanda Krugh \\ West Virginia University \\ Brian LaShier \\ SAIC Corporation \\ Ronald Munson \\ SAIC Corporation
}

Follow this and additional works at: https://researchrepository.wvu.edu/rri_netl

Part of the Regional Economics Commons

\section{Recommended Citation}

Jackson, R., Krugh, A., LaShier, B. Munson, R. (2009). National and State Economic Impact of NETL. DOE National Energy Technology Laboratory. https://researchrepository.wvu.edu/rri_netl/1/

This Article is brought to you for free and open access by the Funded Research Reports at The Research Repository @ WVU. It has been accepted for inclusion in National Energy Technology Laboratory by an authorized administrator of The Research Repository @ WVU. For more information, please contact ian.harmon@mail.wvu.edu. 


\title{
Regional Research Institute West Virginia University
}

Research Paper Series

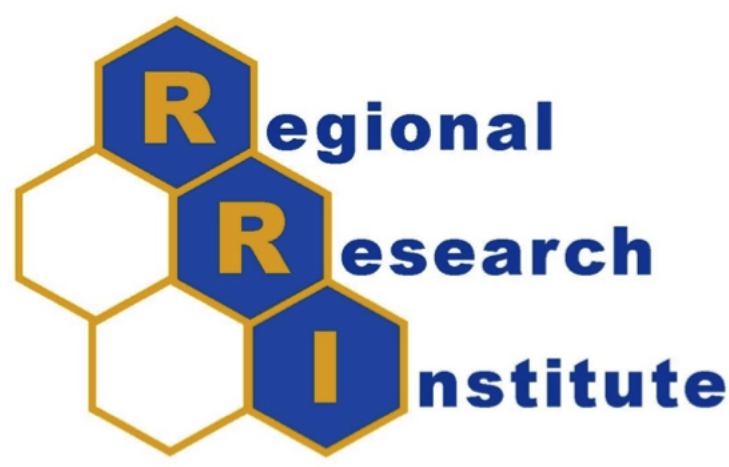

National and State Economic Impact of NETL

\author{
RANDALL JACKSON \\ Regional Research Institute, West Virginia University \\ Amanda KRUGH \\ Regional Research Institute, West Virginia University \\ BRIAN LASHIER \\ SAIC CORPORATION \\ RONALD MUNSON \\ SAIC CORPORATION
}

Date Submitted: October 2, 2009

Keywords: Input-output model, Natural gas and oil, Economic impacts, Employment 


\title{
National and State Economic Impact of NETL
}

\author{
Randall Jackson* \\ Amanda Krugh $\dagger$ \\ Brian LaShier $\ddagger$ \\ Ronald Munson§
}

October 2, 2009

\begin{abstract}
This report documents the development of state-level input-output models for Pennsylvania, West Virginia, and Oregon and the augmentation of the national input-output model that was developed previously for the project Valuing Domestically Produced Natural Gas and Oil. The state IO models were developed to assess the economic impacts of expenditures, employment, and research and development awards at the NETL sites located in Pittsburgh, PA, Morgantown, WV, and Albany, OR. The national IO model was developed to assess the economic impacts of NETL site expenditures, awards, and employment at the national level.
\end{abstract}

\section{Recommended Citation}

Jackson, R., Krugh, A., LaShier, B. Munson, R. (2009). National and State Economic Impact of NETL. DOE National Energy Technology Laboratory. (Add URL where document is located.)

*Regional Research Institute, West Virginia University $\dagger$ Regional Research Institute, West Virginia University $\ddagger$ SAIC Corporation

$\S S A I C$ Corporation 


\section{Disclaimer}

This report was prepared as an account of work sponsored by an agency of the United States Government. Neither the United States Government nor any agency thereof, nor any of their employees, makes any warranty, express or implied, or assumes any legal liability or responsibility for the accuracy, completeness, or usefulness of any information, apparatus, product, or process disclosed, or represents that its use would not infringe privately owned rights. Reference therein to any specific commercial product, process, or service by trade name, trademark, manufacturer, or otherwise does not necessarily constitute or imply its endorsement, recommendation, or favoring by the United States Government or any agency thereof. The views and opinions

of authors expressed therein do not necessarily state or reflect those of the United States Government or any agency thereof. 


\section{Acknowledgements}

This report was prepared by Research and Development Solutions, LLC (RDS) for the United States Department of Energy's National Energy Technology Laboratory. This work was completed under DOE NETL Contract Number DE-AM26-04NT41817. This work was performed under RDS Subtask 41817-402.01.03. The authors wish to acknowledge the excellent guidance, contributions, and cooperation of the NETL staff, particularly:

\section{Lisa Phares, NETL Technical Monitor \\ Gavin Pickenpaugh \\ Phil DiPietro}

RDS also wishes to acknowledge the valuable input to this study provided by Justin Strock and Josh Chad-

dock of Technology \& Management Services, Inc (TMS), but notes that this acknowledgement does not indicate their endorsement of the results of this study. 
$<$ This page blank $>$ 


\section{NATIONAL ENEFCY TECHNOLOCY LABOPATOPY}

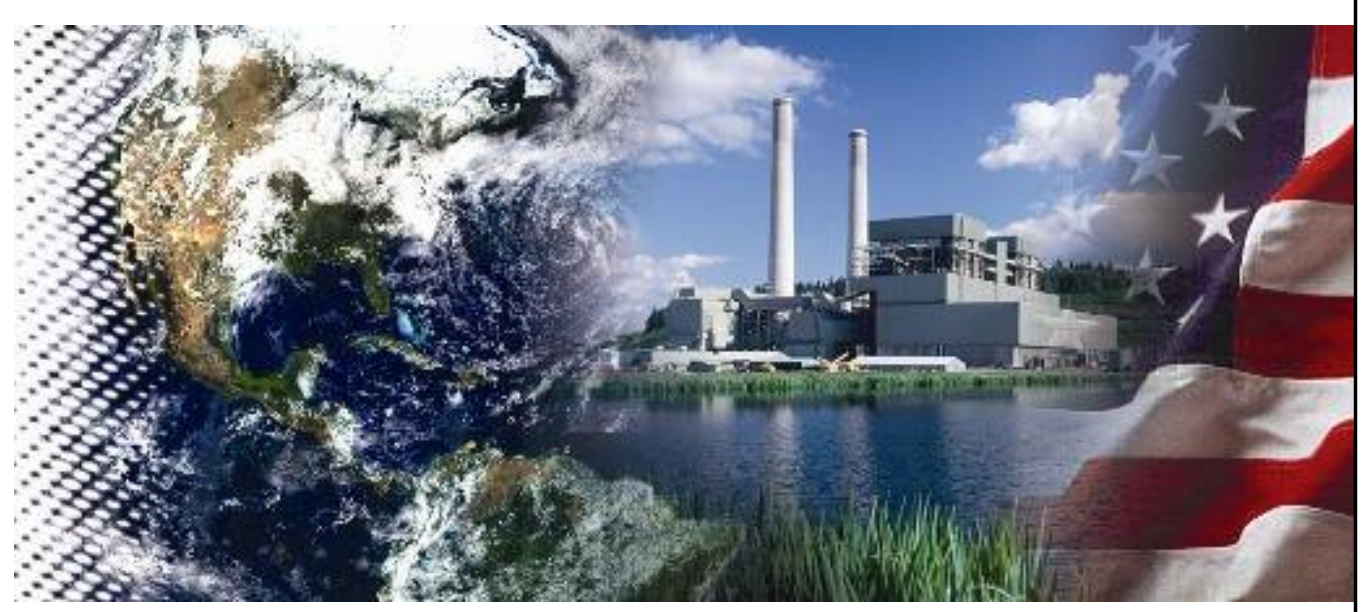

\section{National and State Economic Impact of NETL}

October 2, 2009

DOE/NETL-402/100209 


\section{Disclaimer}

This report was prepared as an account of work sponsored by an agency of the United States Government. Neither the United States Government nor any agency thereof, nor any of their employees, makes any warranty, express or implied, or assumes any legal liability or responsibility for the accuracy, completeness, or usefulness of any information, apparatus, product, or process disclosed, or represents that its use would not infringe privately owned rights. Reference therein to any specific commercial product, process, or service by trade name, trademark, manufacturer, or otherwise does not necessarily constitute or imply its endorsement, recommendation, or favoring by the United States Government or any agency thereof. The views and opinions of authors expressed therein do not necessarily state or reflect those of the United States Government or any agency thereof. 


\section{NATIONAL AND STATE ECONOMIC IMPACT OF NETL}

\section{DOE/NETL-402/100209}

\section{FINAL REPORT}

October 2, 2009

NETL Contact:

Lisa Phares

Economist

Office of Systems, Analyses and Planning

National Energy Technology Laboratory www.netl.doe.gov 
This page intentionally left blank 


\section{Table of Contents}

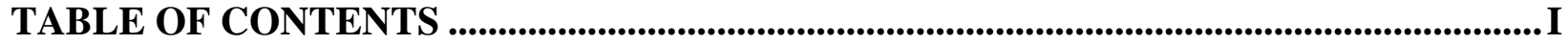

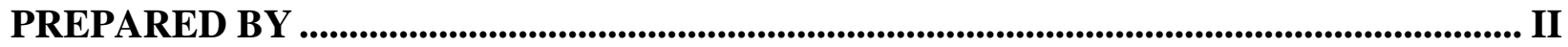

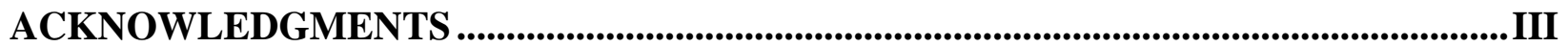

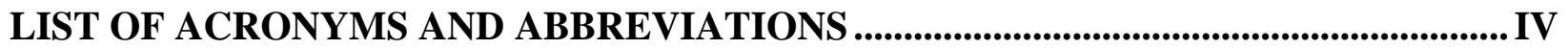

EXECUTIVE SUMMARY ...........................................................................................................1

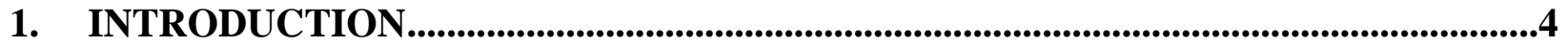

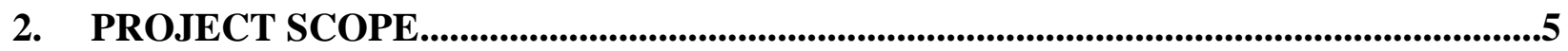

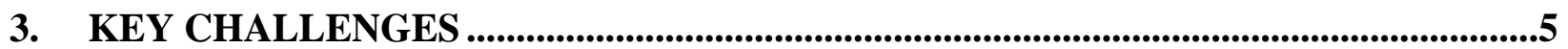

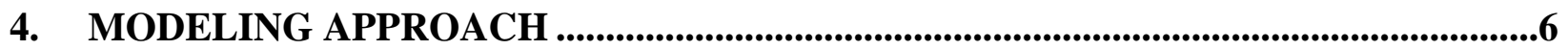

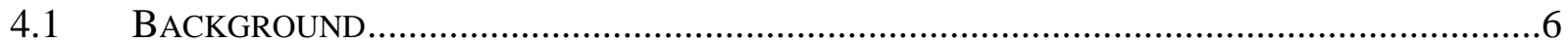

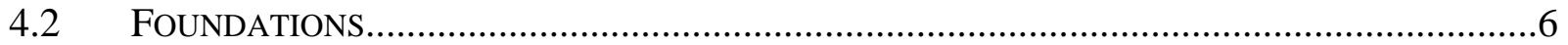

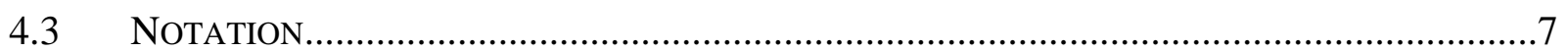

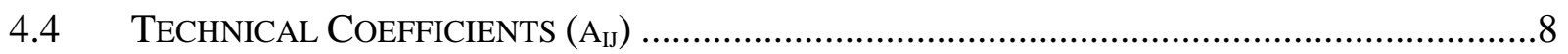

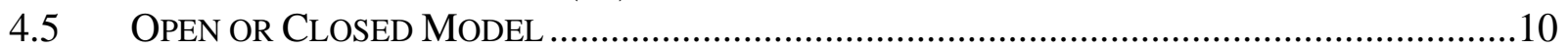

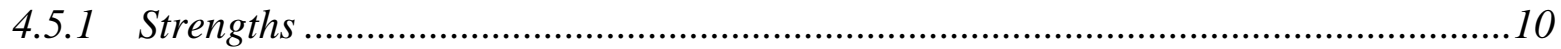

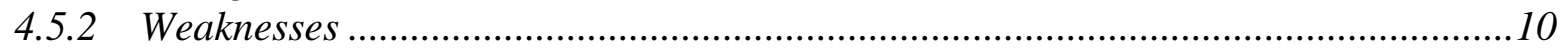

5. MODELS DEVELOPED FOR NETL IMPACT ANALYSIS........................................12

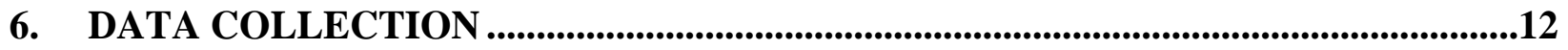

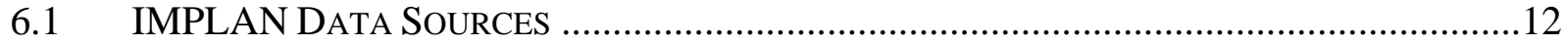

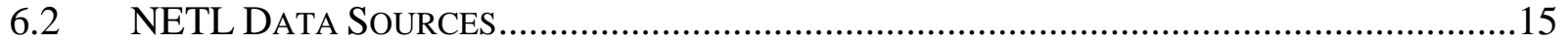

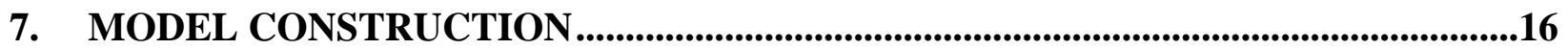

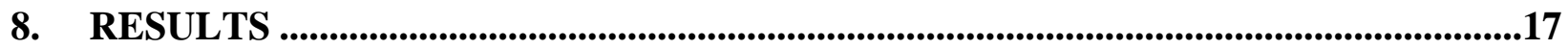

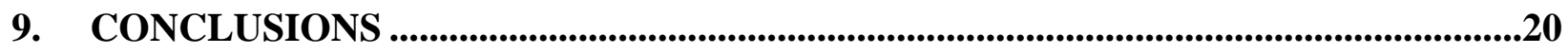

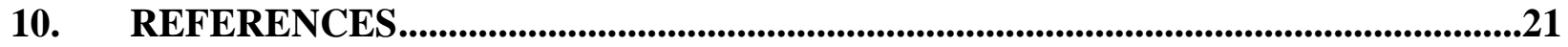




\section{Prepared by:}

Research and Development Solutions, LLC (RDS)

Randall Jackson and Amanda Krugh

West Virginia University

Brian LaShier and Ronald Munson

SAIC Corporation

DOE Contract \#DE-AM26-04NT41817 


\section{Acknowledgments}

This report was prepared by Research and Development Solutions, LLC (RDS) for the United States Department of Energy’s National Energy Technology Laboratory. This work was completed under DOE NETL Contract Number DE-AM26-04NT41817. This work was performed under RDS Subtask 41817-402.01.03.

The authors wish to acknowledge the excellent guidance, contributions, and cooperation of the NETL staff, particularly:

Lisa Phares, NETL Technical Monitor

Gavin Pickenpaugh

Phil DiPietro

RDS also wishes to acknowledge the valuable input to this study provided by Justin Strock and Josh Chaddock of Technology \& Management Services, Inc (TMS), but notes that this acknowledgement does not indicate their endorsement of the results of this study. 


\section{LIST OF ACRONYMS AND ABBREVIATIONS}

CRS Constant Returns to Scale

DOE Department of Energy

FY Fiscal Year

IO Input-Output

NETL National Energy Technology Laboratory

NSS Non Site Support

O\&M Operation and maintenance

RPC Regional Purchase Coefficient

RDS Research and Development Solutions, LLC

WVU West Virginia University 
This page intentionally left blank 


\section{EXECUTIVE SUMMARY}

This report documents the development of state-level input-output models for Pennsylvania, West Virginia, and Oregon and the augmentation of the national input-output model that was developed previously for the project Valuing Domestically Produced Natural Gas and Oil ${ }^{1}$ The state IO models were developed to assess the economic impacts of expenditures, employment, and research and development awards at the NETL sites located in Pittsburgh, PA, Morgantown, $\mathrm{WV}$, and Albany, OR. The national IO model was developed to assess the economic impacts of NETL site expenditures, awards, and employment at the national level.

The primary goal of this project was to develop a fully defensible and transparent means for routinely estimating state and national economic impacts derived from NETL employment and activity. The development of this methodology and these models allows NETL to assess its influence with respect to the regional economy and to evaluate scenarios that represent alternative activity levels and expenditure allocations.

This project expands NETL's analytical capabilities by producing economic models that allow for the calculation of direct, indirect and induced employment, income, and output impacts, and total tax impacts. Further, the work conducted through this collaborative effort lays the groundwork for future analysis to be completed using a consistent methodology.

Constructing new models for economic analysis presents four primary challenges which lead to the identification of several key decision points. The four primary challenges were:

1. Identifying quality data sets for economic parameters;

2. Identifying and collecting NETL data sets;

3. Determining the most appropriate industry sectors for NETL Award expenditures;

4. Defining the most appropriate approach to implementing the model.

The principals guiding the decisions for which data sets to use and which regionalization method to employ were driven by the objective of developing a methodology that is complete, consistent and theoretically sound.

As noted, this project uses input-output (IO) models to derive the economy-wide impacts of NETL's activity. IO models were chosen for this project because they represent the economic relationships between all the sectors of the economy and because the underlying theory of IO models has been well tested and documented. Input-output models are used by economists to trace the direct and indirect requirements from industries for the production and delivery to final

${ }^{1}$ NETL. (2008). Valuing Domestically Produced Natural Gas and Oil. DOE/NETL-2009/1355. 
demand of specified levels of final demand. The final demand is specified on an industry by industry basis. Under the assumption that the input requirements per dollar of output remain constant for the period of analysis, the backward requirements for inputs from each supplying industry are traced through the supply chain.

The analysis reports estimates of the activity accounted for by NETL operations broadly defined. Whereas other approaches can be used to generate "net" benefits relative to alternative expenditure distributions (e.g., net jobs), this assessment pertains to actual expenditures for a given year. Hence, this approach provides estimates of actual impacts of expenditures already allocated.

The data used to represent NETL's 2008 activity at the Pittsburgh, PA, Morgantown, WV, Albany OR sites, and throughout the Nation are presented in Table ES-1. A summary of total impacts is provided in Table ES-2. The Non-Site Support (NSS) Awards are subject to a "translator" process designed to provide a more alternative, detailed description and allocation of award expenditures. This procedure is described in Section 7 of this report. . Table ES-2 provides the summary total impacts with the use of the translator process and the summary total impacts without the use of the translator process for comparison.

Table ES-1. NETL Data

\begin{tabular}{|c|c|c|c|c|c|}
\hline & Region & PA & WV & OR & US* \\
\hline \multirow{5}{*}{ 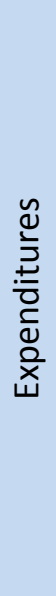 } & NETL Employment & 287 & 218 & 69 & 591 \\
\hline & $\begin{array}{l}\text { NETL Employee } \\
\text { Compensation }\end{array}$ & $\$ 33,799,151$ & $\$ 25,611,324$. & $\$ 7,088,378$ & $\$ 68,377,584$ \\
\hline & $\begin{array}{l}\text { Site Supported } \\
\text { Contractor Awards }\end{array}$ & $\$ 38,257,221$ & $\$ 36,050,419$ & $\$ 386,320$ & $\$ 107,215,403$ \\
\hline & $\begin{array}{l}\text { Non-Site Supported } \\
\text { Contractor Awards }\end{array}$ & $\$ 57,463,160$ & $\$ 11,563,949$ & $\$ 1,059,314$ & $\$ 819,153,330$ \\
\hline & $\begin{array}{l}\text { NETL Operations } \\
\text { Expenditures }\end{array}$ & $\$ 12,846,574$ & $\$ 3,726,180$ & $\$ 4,941,036$. & $\$ 78,685,800$ \\
\hline
\end{tabular}

* The sum of PA, WV and OR does not equal US values due to NETL activity based in other states. 
Table ES-2. Summary of Total Impacts

Translated Total Impacts

\begin{tabular}{|r|r|r|r|}
\hline Region & $\begin{array}{c}\text { Total } \\
\text { Income } \\
(\$ M)\end{array}$ & $\begin{array}{c}\text { Total } \\
\text { Employment }\end{array}$ & $\begin{array}{c}\text { Total } \\
\text { Taxes } \\
(\$ M)\end{array}$ \\
\hline PA & $\$ 154.54$ & 1878 & $\$ 9.41$ \\
\hline WV & $\$ 85.73$ & 1257 & $\$ 4.90$ \\
\hline OR & $\$ 18.41$ & 240 & $\$ 0.91$ \\
\hline US & $\$ 940.96$ & 11208 & $\$ 64.45$ \\
\hline
\end{tabular}

Non Translated Total Impacts

\begin{tabular}{|r|r|r|r|}
\hline Region & $\begin{array}{c}\text { Total } \\
\text { Income } \\
(\$ \mathrm{M})\end{array}$ & $\begin{array}{c}\text { Total } \\
\text { Employment }\end{array}$ & $\begin{array}{c}\text { Total } \\
\text { Taxes } \\
(\$ \mathrm{M})\end{array}$ \\
\hline PA & $\$ 52.66$ & 1877 & $\$ 9.14$ \\
\hline WV & $\$ 85.60$ & 1255 & $\$ 4.90$ \\
\hline OR & $\$ 18.40$ & 239 & $\$ 0.91$ \\
\hline US & $\$ 925.97$ & 11017 & $\$ 64.28$ \\
\hline
\end{tabular}

Rest of the United States Translated Total Impacts

\begin{tabular}{|r|c|c|c|}
\hline Region & $\begin{array}{c}\text { Total } \\
\text { Income } \\
(\$ M)\end{array}$ & $\begin{array}{c}\text { Total } \\
\text { Employment }\end{array}$ & $\begin{array}{c}\text { Total } \\
\text { Taxes } \\
(\$ M)\end{array}$ \\
\hline $\begin{array}{l}\text { U.S. minus } \\
\text { OR,WV,PA }\end{array}$ & $\$ 682.28$ & 7833 & $\$ 49.23$ \\
\hline
\end{tabular}

Rest of the United States Non Translated Total Impacts

\begin{tabular}{|r|c|c|c|}
\hline Region & $\begin{array}{c}\text { Total } \\
\text { Income } \\
(\$ M)\end{array}$ & $\begin{array}{c}\text { Total } \\
\text { Employment }\end{array}$ & $\begin{array}{c}\text { Total } \\
\text { Taxes } \\
(\$ M)\end{array}$ \\
\hline $\begin{array}{l}\text { U.S. minus } \\
\text { OR,WV,PA }\end{array}$ & $\$ 769.31$ & 7646 & $\$ 49.33$ \\
\hline
\end{tabular}




\section{INTRODUCTION}

This project explores state and national level impacts of the NETL facilities located in Pennsylvania, West Virginia, and Oregon. State and national impacts assessment of NETL fiscal year (FY) 2008 employment, operations, and research funding were conducted using NETL employment and activity data as well as IMPLAN aggregated industry data.

The project objective was to develop a means for regularly estimating state-level and national economic impacts generated by NETL employment as well as operational activities, onsite contractor support, and awards that support external research. This project is driven by the need to conduct annual laboratory impact assessments. The analyses and models developed for this project capture the respective state and national economic and employment impacts of the three NETL sites noted. The main goal of this project was to develop the underlying models, assessment methodologies, and a software tool that can be used for current and future impact assessments by NETL and the research partners on this task.

NETL has previously reported impacts of its activities that were estimated using NETL data similar to what was collected for this project. Regional impacts in past analyses were developed to assess the economic and environmental impacts of expenditures and employment at, and research and development awards originating from, the National Energy Technology Laboratory (NETL) sites located in Pittsburgh, PA and Morgantown, WV. The previous project had used a national economic-input-output life-cycle assessment model that allows researchers to include detailed process-level environmental data as well as economy-wide (supply chain) environmental impacts.

Past regional impact analyses are similar to this project in the use of IO modeling and project objectives. However, this project does not consider environmental impacts and uses direct IO modeling instead of a combination of methods. Previous regional IO models were generated differently than those used in this modeling framework. This project extracts Make and Use tables, edits them to include a new "industry sector" representing the onsite federal activities. As a result, the modeling procedure captures these activities more accurately, and also provides a translator mechanism for further refining the final demand specifications corresponding to awards. Further, the work conducted through this effort lays the groundwork for future analyses to be completed using a consistent methodology and protocol from data compilation to reporting through model formulation and results generation. The project's target audiences are governmental decision makers, industry experts and researchers that will utilize the national and state models for their own economic impact analysis. 


\section{PROJECT SCOPE}

This project has resulted in up-to-date state-level models for Pennsylvania, West Virginia, Oregon, and the nation ${ }^{2}$. Additionally, this has generated a standardized NETL data collection process for impact assessments. Although national level economic impact assessment models are appropriate to the estimation of national impacts, it is appropriate to use explicitly regional models for impacts estimates that will be used to inform regional decision-making. The intent of this project was to construct a framework and modeling platform for an input-output analysisbased impact model that will provide a better approximation of impacts of the NETL facilities on their respective states and the nation.

\section{KEY CHALLENGES}

Constructing new models for an economic analysis presented four primary challenges which lead to the identification of several key decision points. The four primary challenges were:

1. Finding quality data sets for economic parameters;

2. Identifying and collecting NETL data,

3. Determining the most appropriate industry sectors for allocating NETL Award expenditures,

4. Defining the most appropriate approach to implementing the model.

The decision criteria that guide the choices arising from these challenges are outlined below. Additional detail on the data collection, model regionalization and model implementation processes are specified in their respective sections of this document.

Economic Data Sets

- Must be consistent with data sources used in the existing national EIO model

- Must be available at the state level for PA, WV, and OR

- Must be most current available (2007)

Methodology for Regionalizing the National Model

- Must follow economic principles

- Must be applicable to existing national model construct

- Must be applicable to data used in the existing national model

NETL Data Sets

- Must include award expenditure, operational, and employment information

2 The national model constructed comprises the fifty states and the District of Columbia. 
- $\quad$ Must be available for 2008

- Must identify NETL site and vendor locations

\section{Model Implementation}

- Select economic sector(s) that best represent NETL

- Determine NETL award allocation by sector

\section{MODELING APPROACH}

Input-output analysis is based on the inter-industry sales and purchase relationships that exist in every economy. IO analysis characterizes an economy by describing these flows of goods and services between industries, institutions, and the final market.

\subsection{BACKGROUND}

François Quesnay (1694-1774), a French physician turned economist was the first to use this type of system to describe the economy. One of his main works, Le Tableau Économique (1758), contained an early, much less sophisticated version of a multi-sector input-output system. He aimed to show diagrammatically the flow of money in a primarily agrarian economy. Later, forms of this technique would be expounded upon by such great economic minds as David Ricardo, Karl Marx, and Léon Walras.

However, it wasn't until the late 1930’s that Wassily Leontief (1906-1999), a Russian-born American economist, developed the analytical framework that would become modern inputoutput analysis. For this substantial contribution to the field he was awarded the Nobel Prize in Economic Science in 1973. In more recent years, input-output analysis has been extended to deal with such things as energy consumption, environmental factors, and employment impacts. It can now also be extended to consider interregional and multiregional analyses.

\subsection{FOUNDATIONS}

The statistical foundation of IO analysis is essentially an accounting framework. The basis of any type of IO system is the transactions matrix. The transactions matrix is a means of ordering all inter-industry sales (outputs) and purchases (inputs) - the economic transactions that occur in the economy - during a given time period. Each column of this matrix consists of the values of the inputs required by a given industry to produce its output. Each row consists of the values of the industry's outputs distributed throughout the economy. This transactions matrix only reports the intermediate goods and services being exchanged among industries.

Additionally, a full input-output table also includes a few additional rows (value added) and additional columns (final demand). The value added rows include information about the nonindustrial inputs of production, such as labor. The final demand columns show the sales by each industry to a final market, such as consumption, investment, government purchases, and net exports. An example of an input-output table is produced below in Figure 1. 


\section{Transactions Table}

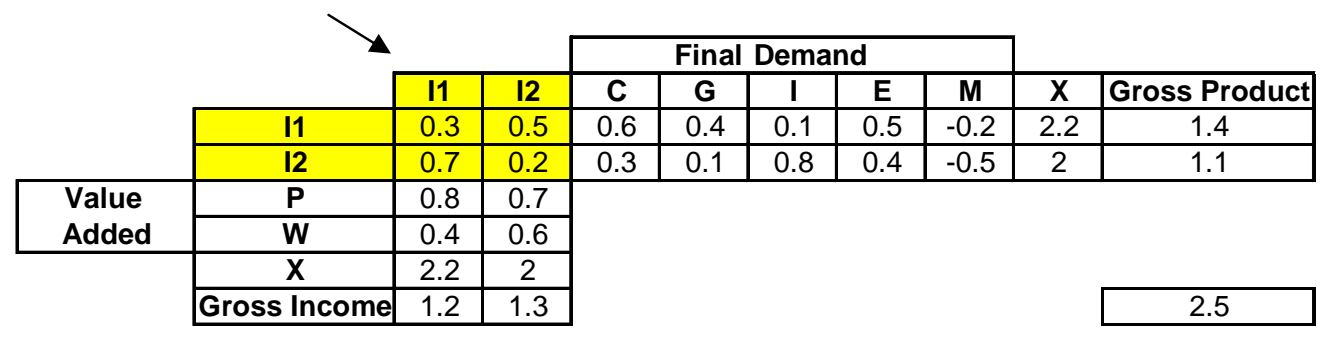

Figure 1: Accounting Foundations of IO Analysis

\subsection{NOTATION}

$\mathbf{Z}$ : transactions matrix

$\mathbf{z}_{\mathbf{i j}} \in \mathbf{Z}$ : dollar flow of commodities from industry i to industry $\mathbf{j}$ on current account

$\mathbf{P}_{\mathbf{j}}$ : profits for industry j

$\mathbf{W}_{\mathbf{j}}$ : wages and salaries for industry $\mathbf{j}$

$\mathbf{v}_{\mathbf{j}}$ : value added for industry $\mathbf{j}$

$\mathbf{C}_{\mathbf{i}}$ : value of flows of commodities from industry i to consumption

$\mathbf{G}_{\mathbf{i}}$ : value of flows of commodities from industry $\mathrm{i}$ to government expenditures

$\mathbf{I}_{\mathbf{i}}$ : value of flows of commodities from industry i to investment

$\mathbf{E}_{\mathbf{i}}$ : value of flows of commodities from industry i to export sales

$\mathbf{M}_{\mathbf{i}}$ : value of imports of commodities for industry i

$\mathbf{f}_{\mathbf{i}}$ : value of flows of commodities from industry i to category $\mathrm{k}$ of final demand (consumption, government expenditures, investment, and export sales)

$\mathbf{X}_{\mathbf{i}}$ : output of industry i

$\mathrm{V}_{\mathrm{j}}=\mathrm{P}_{\mathrm{j}}+\mathrm{W}_{\mathrm{j}}$

$\mathrm{f}_{\mathrm{i}}=\mathrm{C}_{\mathrm{i}}+\mathrm{G}_{\mathrm{i}}+\mathrm{I}_{\mathrm{i}}+\mathrm{E}_{\mathrm{i}}$

Balance Equation for Output 


$$
\left(\sum_{j} z_{i j}\right)+C_{i}+G_{i}+I_{i}+E_{i}=X_{i} \forall i, i=1, \ldots, n
$$

Balance Equation for Input

$$
\left(\sum_{i} Z_{i j}\right)+P_{j}+W_{j}+M_{j}=X_{j} \forall j, j=1, \ldots, n
$$

Total Output

$\sum_{i} \sum_{j} Z_{i j}+\sum_{i}\left(C_{i}+G_{i}+I_{i}+E_{i}\right)=\sum_{i} X_{i}$

Total Input

$\sum_{j} \sum_{i} Z_{i j}+\sum_{j}\left(P_{j}+W_{j}+M_{j}\right)=\sum_{j} X_{j}$

To make economic sense, total outputs must equal total inputs. Then, we can see that:

$\sum_{i} \sum_{j} z_{i j}+\sum_{i}\left(C_{i}+G_{i}+I_{i}+E_{i}\right)=\sum_{j} \sum_{i} z_{i j}+\sum_{j}\left(P_{j}+W_{j}+M_{j}\right)$

$\sum_{i}\left(C_{i}+G_{i}+I_{i}+E_{i}\right)=\sum_{j}\left(P_{j}+W_{j}+M_{j}\right)$

$\mathrm{C}+\mathrm{I}+\mathrm{G}+\mathrm{E}=\mathrm{P}+\mathrm{W}+\mathrm{M}$

$\mathrm{C}+\mathrm{I}+\mathrm{G}+\mathrm{E}-\mathrm{M}=\mathrm{P}+\mathrm{W}$

The left hand side of this final equation is gross national product and the right hand side is gross national income.

\subsection{TECHNICAL COEFFICIENTS $\left(\mathrm{A}_{\mathrm{IJ}}\right)$}

\section{$\underline{\text { Assumptions }}$}

1. Interindustry flows from $i$ to $j$ in a given time period depend solely on the total output for sector $\mathrm{j}$ in that same time period.

2. The technical coefficients are constant and measure fixed relationships between an industry’s output and its inputs. 
3. Production operates under constant returns to scale (CRS).

4. $\quad$ IO analysis requires that an industry uses inputs in fixed proportions.

$$
a_{i j}=\frac{Z_{i j}}{X_{j}}
$$

The technical coefficient, $a_{i j}$, can be interpreted as the dollar's worth of input from industry i per dollar's worth of output of industry $\mathrm{j}$. We can now define the technical coefficients matrix for an n-industry economy, A:

$$
A=\left[\begin{array}{cccccc}
a_{11} & a_{12} & \cdot & \cdot & \cdot & a_{1 n} \\
a_{21} & a_{22} & \cdot & \cdot & \cdot & a_{2 n} \\
\cdot & \cdot & \cdot & & & \cdot \\
\cdot & \cdot & & \cdot & & \cdot \\
\cdot & \cdot & & & \cdot & \cdot \\
a_{n 1} & a_{n 2} & \cdot & \cdot & \cdot & a_{n n}
\end{array}\right]
$$

Using the numbers above in Figure 1, the technical coefficients matrix is defined as:

$$
A=\left[\begin{array}{cc}
.1364 & .25 \\
.3182 & .1
\end{array}\right]
$$

Now, if we let $Y_{i}$ be industry i's sales to final demand:

$Y_{i}=C_{i}+G_{i}+I_{i}+E_{i}$

Then we can write that:

$$
X_{i}=z_{i 1}+z_{i 2}+\ldots+z_{\text {in }}+Y_{i}
$$

Using the equation for technical coefficients above:

$$
\mathrm{X}_{\mathrm{i}}=a_{\mathrm{i} 1} \mathrm{X}_{1}+a_{\mathrm{i} 2} \mathrm{X}_{2}+\ldots+a_{\mathrm{in}} \mathrm{X}_{\mathrm{n}}+\mathrm{Y}_{\mathrm{i}}
$$

By manipulating this equation in matrix form we can define the complete system as:

$$
(\mathrm{I}-\mathrm{A}) \mathrm{X}=\mathrm{Y} \quad \text { or } \quad \mathrm{X}=(\mathrm{I}-\mathrm{A})^{-1} \mathrm{Y}
$$

where, I corresponds to the (nxn) identity matrix and (I-A $)^{-1}$ is called the Leontief inverse.

The Leontief inverse referencing Figure 1 is:

$$
(I-A)^{-1}=L=\left[\begin{array}{cc}
1.28997 & .3583 \\
.45608 & 1.2378
\end{array}\right]
$$


To show the dependence of the gross outputs on the values of the final demands we can define the elements of the Leontief inverse as $l_{\mathrm{ij}}$ and write the equation:

$$
\mathrm{X}_{\mathrm{i}}=l_{\mathrm{i} 1} \mathrm{Y}_{1}+l_{\mathrm{i} 2} \mathrm{Y}_{2}+\ldots+l_{\text {in }} \mathrm{Y}_{\mathrm{n}}
$$

\subsection{OPEN OR CLOSED MODEL}

The IO model can either be open or closed with respect to households. The difference between an open model and a closed model is that households are exogenous in the open model and endogenous in the closed model. In a closed model, households are treated as part of the production sector and are therefore economically connected with all other parts of the transactions matrix. This addition adds one extra row and column to the transactions matrix, the matrix of technical coefficients, and the Leontief inverse. The household sector can be thought of as equivalent to an industry that buys consumer goods from and sells labor to all other industries. Given the project goal of modeling the direct, indirect, and induced impacts of the three NETL offices and operations, we use a model that it closed with respect to households as the base analytical framework.

\subsubsection{Strengths}

- $\quad$ IO models provide a large amount of information in a concise and easy-to-understand form. They present a comprehensive picture of the economy and its inter-industry relations.

- $\quad$ IO analysis is transparent; it does not rest on as many assumptions and parameters as some of the models that are discussed later in this document.

- $\quad$ Extremely useful in analyzing the impact of a change in any sector on the output of others.

- $\quad$ One main attribute of IO analysis is its descriptive analytical power. It has predictive capabilities in that it can estimate both direct and indirect impacts as they are tracked through the economy.

- $\quad$ IO analysis analyzes changes and impacts on an industry-by-industry level, tracing the flow of dollars between industries. Therefore, it is possible to have a very precise calculation of the economic impacts to the economy.

- $\quad$ The extension of an IO model to an interregional or multiregional framework is straightforward.

\subsubsection{Weaknesses}

- $\quad$ Constructing transactions matrices can be costly and time-consuming. These data, however, are often collected by government agencies and are available for use but with some significant time lag. 
- $\quad$ An IO matrix gives a static view of the economy and can make structural projection difficult. However, with a significant level of complication, input-output models can be transformed into dynamic models. With required data and economic assumptions, it is also possible to make changes to the initial IO model in order to model different time periods by assuming that technical coefficients are stable over time. As a tool for quantifying the effects of an existing activity, however the static representation of the economic structure accurately reflects activities already in place.

- $\quad$ IO analysis does not allow for interaction between supply and demand. Prices of capital, labor, and intermediate inputs are fixed.

- IO models are not constrained by supply or capacity constraints; although these could be handled with the external processing of data. As a tool for quantifying the effects of an existing activity, the lack of supply constraints is not a significant issue. The lack of supply constraints becomes a more substantial issue in the context of predicting the impacts of new activity.

- $\quad$ The linear relationships assumed in IO analysis do not allow for externalities or increasing/decreasing returns to scale. Again, however, as a tool for quantifying the effects of an existing activity, the significance of this assumption is minimal.

- $\quad$ There is no statistical test to check the model specification.

- $\quad$ Unlike other methods, such as cost-benefit analysis, IO is sometimes criticized for not providing an assessment of net impacts relative to alternate expenditure allocations. However, the objective of this exercise is to estimate the impacts of recent rather than future NETL operations. Hence, since the goal of this exercise is to provide assessments of expenditures already allocated rather than determining some alternative optimal allocation distribution, there is no attempt to generate net benefits. 


\section{MODELS DEVELOPED FOR NETL IMPACT ANALYSIS}

This project incorporates several assumptions into the study design. These assumptions impact the results and should be taken into consideration when analyzing, interpreting and applying the results generated from the project model.

Since the project uses the economic input-output modeling framework, all of the assumptions underlying input-output are relevant. Among those assumptions are the following:

1. The economy can be represented by a set of linear equations with parameters derived primarily from data developed by the Bureau of Economic Analysis. Production is represented as a linear function.

2. The 2007 data upon which the economic model is based are the most recent data available. These data used are assumed to be representative of current economic structure.

3. Impact estimates are interpreted as average impacts, such as average employment per economic sector.

For a given amount of input of operational expenditures, salary and benefits, and award information from NETL PA, WV and OR facilities, the output includes information regarding the impact of these facilities on the regional and national economies and job creation. Impacts results include industry-specific numbers of full time equivalents (jobs), income, output, and value added by component. Value added components include household compensation, proprietors' income, other property type income, and indirect business taxes, all of which follow standard national accounting convention definitions. The model also generates an array of estimated tax impacts.

\section{DATA COLLECTION}

\subsection{IMPLAN DATA SOURCES}

Software and data purchased from the Minnesota IMPLAN Group, Inc. forms the foundation for the regional IO models and for the national IO model. All of the models have been constructed with the IMPLAN software, using 2007 structural and region-specific data.

Within each model, trade flows - the transfer of goods and services between the region and the rest of the world - are estimated using the average regional purchase coefficient (RPC) method. The RPC method estimates trade flows based on econometric equations internal to IMPLAN. These equations are based upon a number of regional-to-national variables, including the wage ratio, "other costs" ratios, output ratios, the commodity weight/value ratio, the ratio of the number of users of a good, the ratio of the number of producers of a good and the land area ratio.

The following data were extracted from IMPLAN and saved in spreadsheet form for use in the impacts assessment model: 
- $\quad$ Regional Use Table - contains information on the use of commodities by industry (the dollar value of purchases of goods and services by each industry for use in the production process)

- Regional Make Table - contains the information on the output distribution of commodities by industry (the dollar value of each good and service produced by each industry)

- Total Commodity Imports - sum of intermediate and institutional imports of commodities (goods and services)

- Total Commodity Final Demand - institutional demand for the final use of commodities (includes the household consumption portion of final demand)

- Employment by Industry - total employment (number of jobs) for each industry (sector)

- $\quad$ Tax Multipliers - multipliers for all tax variables, including business taxes (expressed in dollars by type per dollar of industry output)

To capture direct, indirect and induced impacts on various economic parameters, industry-level data (i.e. production, operational expenditures, employment, awards, etc.) were collected, processed and analyzed. An important consideration in determining the level of industry detail to incorporate into this study is the relevance of a given industry in the scope of the project. The industry schema used in this project's models is shown in Table 1. The schema was derived by aggregating IMPLAN industries and is largely consistent with industry schemas used by the Bureau of Economic Analysis, but is altered slightly to provide granularity in sectors relevant to NETL such as coal mining, architectural and engineering services and scientific R\&D services. 
Table 1. Industry Schema Used in Project Models

\begin{tabular}{|c|c|c|c|c|c|}
\hline $\begin{array}{l}\text { IMPLAN } \\
\text { Codes }\end{array}$ & Industry Description & $\begin{array}{l}\text { IMPLAN } \\
\text { Codes }\end{array}$ & Industry Description & $\begin{array}{l}\text { IMPLAN } \\
\text { Codes }\end{array}$ & Industry Description \\
\hline $1-13$ & Farms & $344-350$ & Motor vehicle, bodies and trailers, and parts & 439 & Architectural and engineering services \\
\hline $14-18$ & Forestry, fishing and related activities & $351-361$ & Other transportation equipment & 445 & Environmental and other technical consulting \\
\hline 19 & Oil and gas extraction & $362-373$ & Furniture and related products & 446 & Scientific research and development services \\
\hline 20 & Coal mining & $374-389$ & Miscellaneous manufacturing & 451 & Management of companies and enterprises \\
\hline $21-26$ & Mining, except coal, oil and gas & 390 & Wholesale trade & $452-459$ & Administrative and support services \\
\hline 27 & Drilling oil and gas wells & 391 & Air transportation & 460 & Waste management and remediation services \\
\hline 28 & Support activities for oil and gas operations & 392 & Rail transportation & 461 & Elementary and secondary schools \\
\hline 29 & Support activities for other mining & 393 & Water transportation & 462 & Colleges- universities- and junior colleges \\
\hline 30 & Power generation and supply & 394 & Truck transportation & 463 & Other educational services \\
\hline 31 & Natural gas distribution & 395 & Transit and ground passenger transportation & $464-466$ & Ambulatory health care services \\
\hline $\begin{array}{c}32 \\
33-40\end{array}$ & Water- sewage and other systems & 396 & Pipeline transportation & $467-468$ & Hospitals and nursing and residential care facil \\
\hline $42-45$ & $\begin{array}{l}\text { Construction, all other } \\
\text { Miscellaneous new construction, including power }\end{array}$ & 397-399 & Other transportation and support activities & $469-470$ & Social assistance \\
\hline $46-91$ & Food and beverage and tobacco products & $401-412$ & Retail trade & $476-478$ & Amusements, gambling, and recreation industr \\
\hline $92-103$ & Textile mills and textile product mills & $413-417$ & Publishing industries (includes software) & $479-480$ & Accommodation \\
\hline $104-111$ & Apparel and leather and allied products & $418-419$ & Motion picture and sound recording industries & 481 & Food services and drinking places \\
\hline $112-123$ & Wood products & $420-422$ & Broadcasting and telecommunications & $482-494$ & Other services, except government \\
\hline $124-135$ & Paper products & $423-424$ & Information and data processing services & $\begin{array}{c}495 \\
496,505\end{array}$ & Federal electric utilities \\
\hline $136-141$ & Printing and related support activities & 425,430 & Federal Reserve banks, credit intermediation, etc. & 506 & Federal, other \\
\hline $142-146$ & Petroleum and coal products & 426 & Securities, commodity contracts, and investments & $\begin{array}{c}498 \\
497,499\end{array}$ & State and local government electric utilities \\
\hline $147-171$ & Chemical products & $427-428$ & Insurance carriers and related activities & $503-504$ & State \& Local \\
\hline $172-181$ & Plastics and rubber products & 429 & Funds, trusts, and other financial vehicles & 500 & Noncomparable imports \\
\hline $182-202$ & Nonmetallic mineral products & 431 & Real estate & 501 & Scrap \\
\hline $203-223$ & Primary metals & $432-436$ & Rental/leasing services/lessors of intangible assets & 502 & Used and secondhand goods \\
\hline $224-256$ & Fabricated metal products & 437 & Legal services & 507 & Rest of the world adjustment to final uses \\
\hline $\begin{array}{l}302-324 \\
325-343\end{array}$ & $\begin{array}{l}\text { Machinery } \\
\text { Computer and electronic products } \\
\text { Electrical equipment, appliances, and components }\end{array}$ & $\begin{array}{l}441-443 \\
438,440 \\
444,447- \\
\quad 450\end{array}$ & $\begin{array}{l}\text { Computer systems design and related services } \\
\text { Miscellaneous professional, scientific, and technical } \\
\text { services }\end{array}$ & 508 & Inventory valuation adjustment \\
\hline
\end{tabular}




\subsection{NETL DATA SOURCES}

- As indicated above, the goal of this project was to develop a means to estimate national and state-level (PA, WV, and OR) economic impacts derived from NETL employment and activity. The most current (2008) NETL data was used for input into the model and then deflated using either IMPLAN or BEA deflators to 2007 dollars for consistency with the IMPLAN model data. Results are represented in 2008 dollars.

Specifically, some of the NETL data categories and sources are summarized as follows:

- NETL (Federal Wages/Salaries)

The source of the NETL Federal wages and salaries data (calendar year 2008) was NETL's Human Resources Division. For each federal employee at NETL, the data required include the assigned work site (e.g., Pittsburgh, Morgantown or Albany,), the state of residence, the annual unburdened salary, a multiplier for benefits, and the total burdened salary (salary plus benefits).

\section{- NETL (Operational Expenditures)}

The Operational Expenditures Data for FY2008 were provided by the Information Technology Division. As used in this context, operational expenditures constitute materials purchased - everything from paper towels to computers to complex laboratory equipment. The purchasing site and home state for each vendor were recorded to enable an accounting of purchases by geographic origin. The impacts of the operational expenditures were determined by the state location of the vendor.

- R\&D Non Site Support (NSS) Awards - 2008 Fiscal year (10/01/07 - 09/30/08) The Data regarding Awards to Contractors that are not Site Support Contractors for FY2008 came from NETL's ProMIS database. Data collected include:

o Award by type: Firm Fixed Price, Cost Plus Fee, Project Grant, etc.

o Business type (award recipient): Government, Non-profit organization, Private higher education institute, etc.

o Home state of awardee

o Award value (government + awardee shares)

o FY08 actual costs

o Value by performer (e.g. prime and sub contractors)

o Project duration

o Performer name

Typically, 'awards' are not attributed to a particular NETL site, but include all awards made at all sites. Regardless, award data provided by the NETL project tracking system do provide information assumed to be sufficient to model award impacts in the state where the awardee is located. Once the data are collected, the performers were mapped to industries listed in Table 1. 


\section{- Site Support Contractor (Wages/Salaries and Expenditures)}

The source for Site Supported Contractor data is the Office of Crosscutting Functions. Targeted requests were sent to each site-support contractor, and the following information was gathered:

o Name, business address, and ZIP Code of the prime contractor

o FY2008 total cost, where possible broken out by NETL site,

o Name, business address, and ZIP Code of each subcontractor/consultant employed during the FY - where possible, broken out by NETL worksite

Project personnel interacted closely with individuals from the above organizations who provided all of the data necessary for model development and application. Based upon the data formats provided by the various NETL groups and organizations, standardized data collection vehicles were developed that can be used to collect the data in future years. These data collection vehicles were developed to make future data collection efforts seamless from the standpoint of both those collecting the data and for those executing the models.

\section{MODEL CONSTRUCTION}

The models developed for this project are Excel-based applications that include regional and national models that achieve the stated project objectives. The models include an interactive (though not necessarily graphical) user interface with the following features:

a) Provides as much flexibility to the user as possible, enabling a high level of user control. The user can enter values for operational expenditures, wages and salaries, and awards.

b) Easily allows for multiple runs against a range of scenarios.

c) Facilitates annual IMPLAN updates.

d) Facilitates flexible industry sector assignments for research awards.

e) Produces results that can easily be incorporated in report form.

The primary input-output database - IMPLAN - is a widely used software and database package, and lists hundreds of universities, public and private institutions among its clients. The IMPLAN database was used to construct the regional and national input-output tables, and then the IO models were developed in Excel spreadsheet format.

The Excel spreadsheet IO models were created using IMPLAN data and NETL information. NETL Vendor data augmented the IMPLAN MAKE and USE tables, effectively forming a separate "NETL O\&M" sector. NETL Federal Employee wage data also were used as the O\&M value added in the USE table. Non-Site Support (NSS) and Site-Support Contractor award expenditures were combined and formed the basis of the final demand vectors that drive the 
models. The final demand entry for the NETL O\&M sector corresponds to the sum of vendor data and federal employee wage estimates. Final demands then drive the respective models and generate results in the form of a total output vector. The relationships between output and employment, employment compensation, and the remainder of value added are used to calculate impact for these categories, and for taxes.

The Non-Site Support (NSS) Awards are subject to a "translator" process designed to provide a more detailed description and allocation of award expenditures. The NSS awards are initially assigned a sector based on the facility/operator sector category of the recipient. The translator process allows a single award to be allocated to multiple sectors through a sector weighting process. These weights allow for a more refined distribution of expenditures across the assigned sectors for each award. The translator process must be implemented by a user exercising professional judgment based on the comprehensive description of the award in the database provided. This process is beneficial in accounting for awards expenditures that may impact multiple sectors. For example, awards initially allocated solely to the IMPLAN sector Junior Colleges, Colleges, Universities, and Professional schools typically conduct scientific research and development services as a part of their award expenditures. As such, the award activities more closely resemble the scientific research and development services sector than the education sector. The Scientific research and development services is an IMPLAN designated sector and therefore funds awarded by NETL to the Junior Colleges, Colleges, Universities, and Professional schools sector should also reflect the Scientific research and development services sector. Using the translator process described above provides a means for designating more appropriate award allocations by sector. Table 2 illustrates this process.

\section{Table 2. Award translator example}

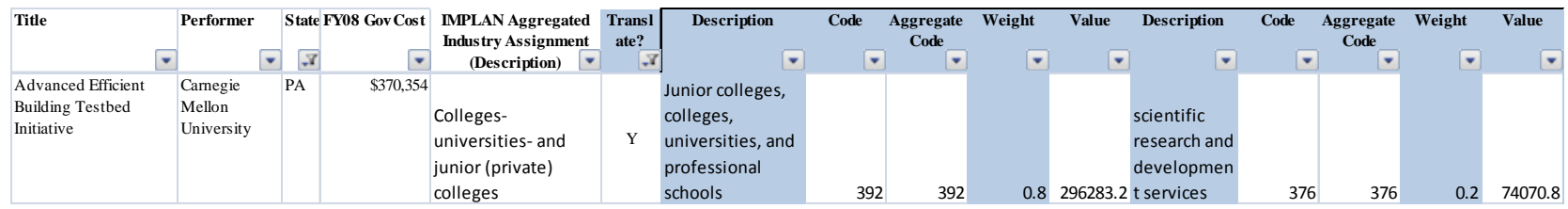

\section{RESULTS}

The IO regional and national models developed for this project provide information on the economic impact of NETL activities at regional and national levels. The state level IO models for the Pittsburgh, PA, Morgantown WV, and Albany OR offices were developed to assess the economic impacts of expenditures, employment, and research and development awards at the NETL sites for the respective states. The national IO model was developed to assess the economic impacts of NETL site expenditures, awards, and employment at the national level. The top ten sectors impacted by NETL activities represented by the results of the regional and national models are shown below. While there is variation across regions, there are some sectors that are present in the top ten for all of the geographic areas. The Operations and Maintenance sector representing NETL operational expenditures, is expectedly impacted heavily by NETL activities. Also present in the top ten impacted sectors for all of the models is the State, Local, and Other sector. This sector contains the State and Weatherization award programs and funding associated with this type of award. The retail trade sector is also relatively heavily impacted by 
NETL activities, as a consequence of its role in all final consumption. The regional and national model impacts to the top ten industries per region are shown in Table 3.

Table 3. Top Ten Industry Impacts per Region

PA Top 10 Industry Impacts

\section{Translated Impacts}

\begin{tabular}{|c|c|c|c|c|c|c|c|}
\hline & & & & & Value Added & & \\
\hline Industry Names & Output (M\$) & $\begin{array}{l}\text { Employment } \\
\text { (FTEs) }\end{array}$ & $\begin{array}{l}\text { Employee } \\
\text { Compensation } \\
\text { (M\$) }\end{array}$ & $\begin{array}{l}\text { Proprietors } \\
\text { Income (M\$) }\end{array}$ & $\begin{array}{l}\text { Property Type } \\
\text { Income (M\$) }\end{array}$ & $\begin{array}{l}\text { Indirect } \\
\text { Business Tax } \\
\text { (M\$) }\end{array}$ & Total (M\$) \\
\hline O\&M & $\$ 50.23$ & 287 & $\$ 33.80$ & $\$ 0.00$ & $\$ 0.00$ & $\$ 0.00$ & $\$ 33.80$ \\
\hline State \& Local, other & $\$ 17.62$ & 249 & $\$ 13.99$ & $\$ 0.00$ & $\$ 1.17$ & $\$ 0.00$ & $\$ 15.16$ \\
\hline Wholesale trade & $\$ 19.75$ & 102 & $\$ 7.12$ & $\$ 0.48$ & $\$ 2.44$ & $\$ 2.82$ & $\$ 12.86$ \\
\hline $\begin{array}{l}\text { TVIscellaneous professional, } \\
\text { scientific, and technical }\end{array}$ & $\$ 14.12$ & 93 & $\$ 4.73$ & $\$ 1.50$ & $\$ 2.62$ & $\$ 0.13$ & $\$ 8.98$ \\
\hline Retail trade & $\$ 12.23$ & 168 & $\$ 4.55$ & $\$ 0.57$ & $\$ 1.51$ & $\$ 1.87$ & $\$ 8.48$ \\
\hline Real estate & $\$ 9.79$ & 52 & $\$ 0.72$ & $\$ 0.79$ & $\$ 5.31$ & $\$ 1.21$ & $\$ 8.03$ \\
\hline $\begin{array}{l}\text { Architectural and engineering } \\
\text { services }\end{array}$ & $\$ 11.91$ & 99 & $\$ 5.72$ & $\$ 1.71$ & $\$ 0.00$ & $\$ 0.06$ & $\$ 7.48$ \\
\hline $\begin{array}{l}\text { Imputed rental activity for } \\
\text { owner-occupied dwellings }\end{array}$ & $\$ 10.83$ & 1 & $\$ 0.00$ & $\$ 0.00$ & $\$ 5.88$ & $\$ 1.19$ & $\$ 7.07$ \\
\hline $\begin{array}{l}\text { Colleges, universities, and } \\
\text { junior (private) colleges }\end{array}$ & $\$ 8.84$ & 98 & $\$ 4.76$ & $\$ 0.09$ & $\$ 0.08$ & $\$ 0.08$ & $\$ 5.00$ \\
\hline $\begin{array}{l}\text { Miscellaneous new } \\
\text { construction, including power } \\
\text { plants }\end{array}$ & $\$ 10.46$ & 83 & $\$ 3.31$ & $\$ 1.16$ & $\$ 0.29$ & $\$ 0.06$ & $\$ 4.81$ \\
\hline
\end{tabular}

WV Top 10 Industry Impacts

\section{Translated Impacts}

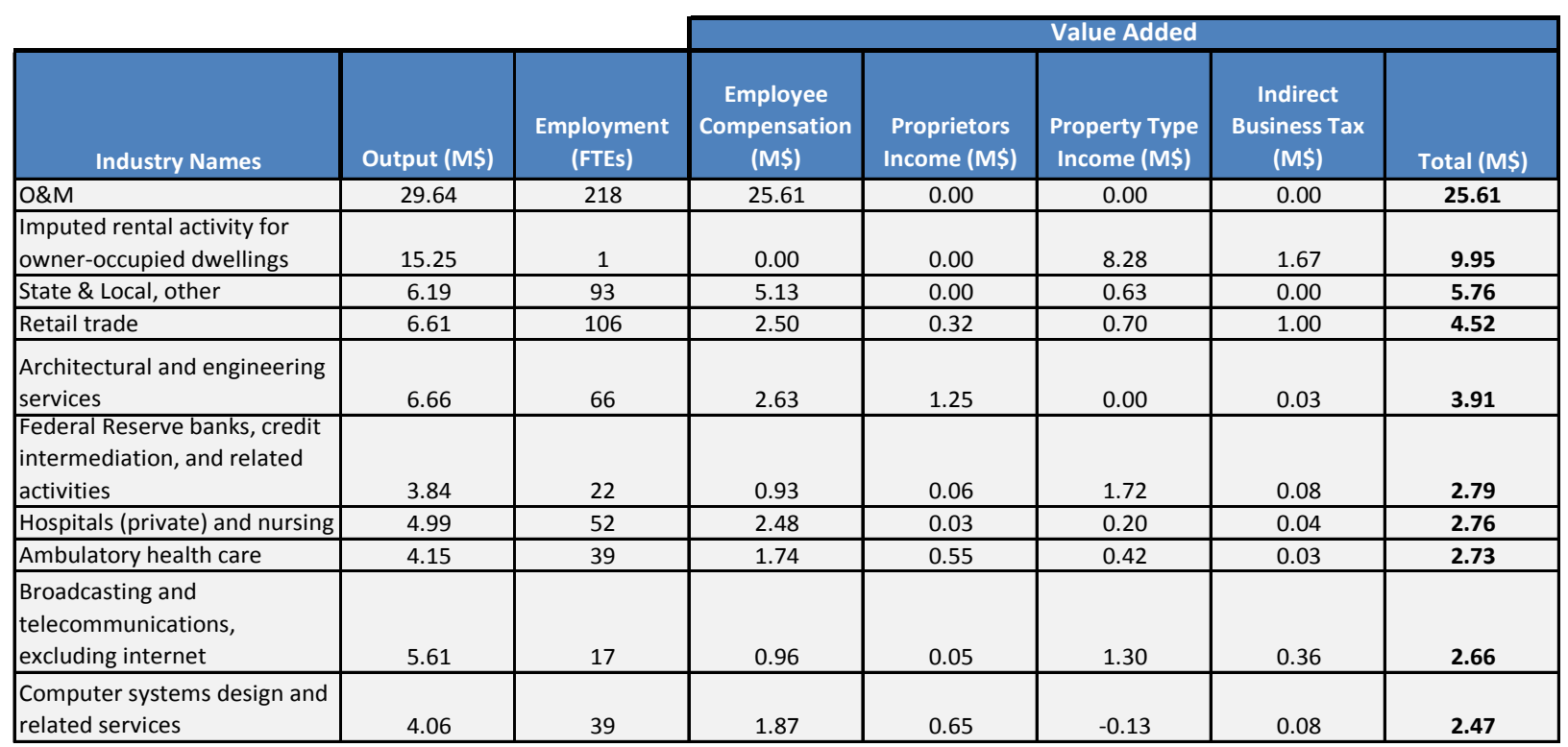




\begin{tabular}{|c|c|c|c|c|c|c|c|}
\hline \multirow[b]{2}{*}{ Industry Names } & \multirow[b]{2}{*}{ Output (M\$) } & \multirow[b]{2}{*}{$\begin{array}{l}\text { Employment } \\
\text { (FTEs) }\end{array}$} & \multicolumn{5}{|c|}{ Value Added } \\
\hline & & & $\begin{array}{c}\text { Employee } \\
\text { Compensation } \\
\text { (M\$̣) }\end{array}$ & $\begin{array}{l}\text { Proprietors } \\
\text { Income (M\$\$) }\end{array}$ & $\begin{array}{l}\text { Property Type } \\
\text { Income (M\$̦) }\end{array}$ & $\begin{array}{c}\text { Indirect } \\
\text { Business Tax } \\
\text { (M\$) }\end{array}$ & Total (M\$̦) \\
\hline O\&M & 12.27 & 69 & 7.09 & 0.00 & 0.00 & 0.00 & 7.09 \\
\hline State \& Local, other & 4.24 & 60 & 3.38 & 0.00 & 0.33 & 0.00 & 3.70 \\
\hline Imputed rental activity for & 2.84 & 1 & 0.00 & 0.00 & 1.54 & 0.31 & 1.85 \\
\hline Retail trade & 1.60 & 22 & 0.62 & 0.06 & 0.18 & 0.25 & 1.11 \\
\hline Ambulatory health care & 0.97 & 7 & 0.42 & 0.10 & 0.11 & 0.01 & 0.64 \\
\hline Wholesale trade & 0.97 & 5 & 0.34 & 0.03 & 0.12 & 0.14 & 0.63 \\
\hline Hospitals (private) and nursing & 0.99 & 10 & 0.50 & 0.04 & 0.05 & 0.01 & 0.59 \\
\hline Federal Reserve banks, credit & 0.84 & 4 & 0.23 & 0.01 & 0.32 & 0.02 & 0.59 \\
\hline Computer and electronic & 1.39 & 4 & 0.44 & 0.00 & 0.01 & 0.02 & 0.47 \\
\hline Fabricated metal products & 1.33 & 6 & 0.30 & 0.01 & 0.15 & 0.01 & 0.47 \\
\hline $\begin{array}{l}\text { Insurance carriers and related } \\
\text { activities }\end{array}$ & 1.13 & 5 & 0.30 & 0.02 & 0.09 & 0.03 & 0.44 \\
\hline
\end{tabular}

US Top 10 Industry Impacts

\section{Translated Impacts}

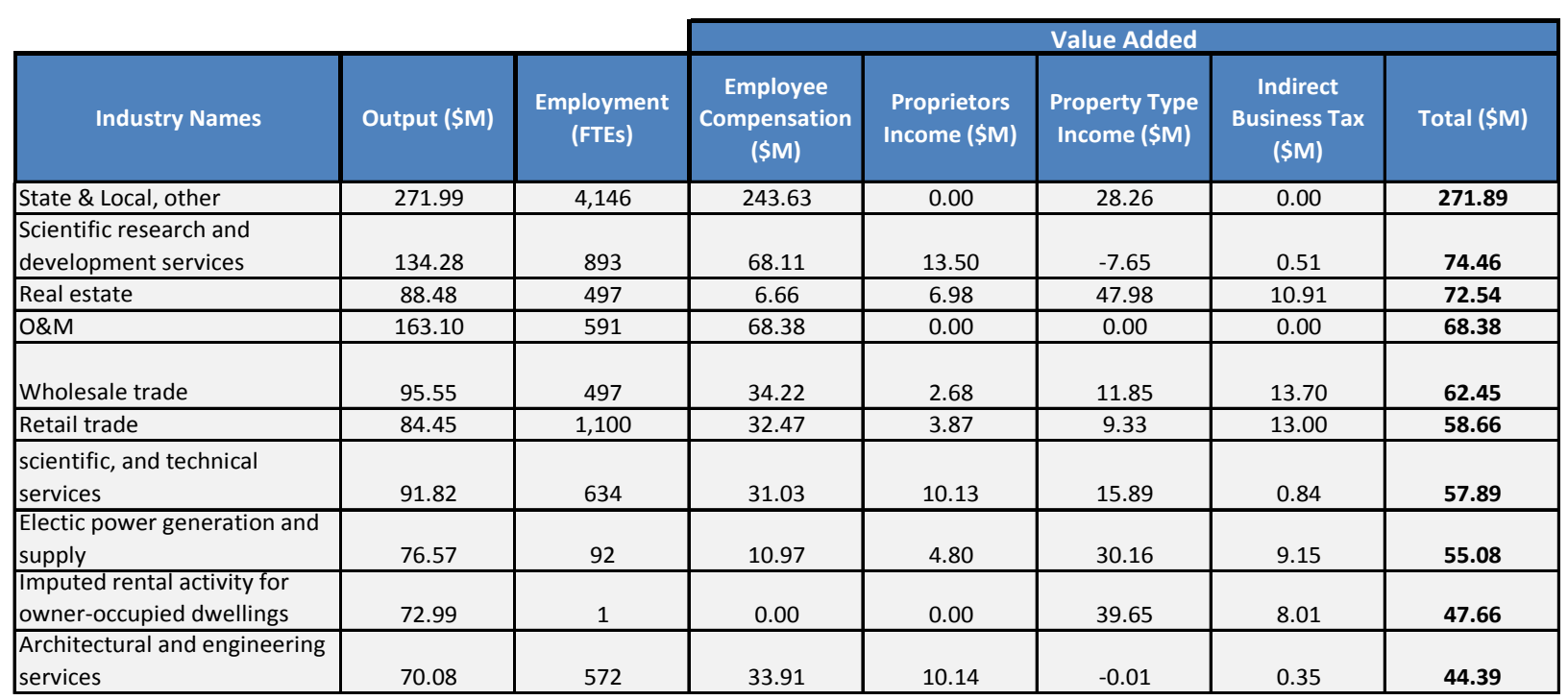




\section{CONCLUSIONS}

This project provides a basis for annual laboratory impact assessments of NETL facilities, standardization of NETL data collection for annual impact assessments, and development of models and an assessment methodology that can be used by NETL and its partner research universities for current and future impact assessments. This project provides the means to identify geographic differences in impacts of changing economic structure, allows for the estimation of economic impacts of the actions of PA, WV, and OR NETL facility actions and job creation. The models and methods developed for this project will benefit and guide future NETL economic impact assessments.

With an established protocol in place, analysts in future years will have the benefit of a more thorough understanding of data requirement and reporting needs, including the most useful formats for data provision. Annual updating tasks will include updating the regional and national models with new data, presumably from IMPLAN. Updates will not only reflect changes in activity level by geographic region, but also often reflect changes in industry classification schemes. For each update year, analysts will need to ensure consistency with industrial sectoring schemes, and will need to generate and extract the necessary tables for use in the spreadsheet models. Further, it remains the task of the analyst to inspect the awards data to make determinations as to whether to apply translators and if so, what the translator composition should be. 


\section{REFERENCES}

1. Hewings, Geoffrey J.D. (1985). Regional Input-Output Analysis. Beverly Hills: Sage Publications.

2. Miller, Ronald E. \& Peter D. Blair. (1985). Input-Output Analysis: Foundations and Extensions. Englewood Cliffs, NJ: Prentice Hall.

3. Miller, Ronald E. \& Peter D. Blair. (1985). Input-Output Analysis: Foundations and Extensions. Englewood Cliffs, NJ: Prentice Hall.

4. Bureau of Economic Analysis, "State Annual Personal Income,” http://www.bea.gov/bea/regional/spi/ (accessed March 12, 2008).

5. U.S. Bureau of Labor Statistics, "Quarterly Census of Employment and Wages (ES-202) Program,” http://www.bls.gov/cew/cewover.htm. (accessed April 2, 2007).

6. U.S. Census Bureau, “2002 Numerical List of Manufactured and Mineral Products,” http://www.census.gov/prod/ec02/02numlist/02numlist.html (accessed April 3, 2007).

7. Bureau of Economic Analysis, "Input-Output Accounts Data: Annual Tables,” http://www.bea.gov/bea/dn2/i-o annual.htm (accessed December 8, 2006).

8. Economic Research Service, http://www.ers.usda.gov/data/farmincome/finfidmu.htm (accessed December 16, 2006).

9. NAICS codes described in NAICS Census homepage: http://www.census.gov/epcd/www/naics.htmsl (accessed July 5, 2007)

10. NETL. (2008). Valuing Domestically Produced Natural Gas and Oil. DOE/NETL2009/1355. 